\title{
УГОЛОВНОЕ ПРАВО
}

\author{
DOI: 10.17803/1994-1471.2021.130.9.114-123
}

\section{Е. В. Благов*}

\section{O понятии соучастника преступления}

Аннотация. Анализируются содержание и объем понятия соучастника преступления. В отношении содержания отмечается, что дефиниция соучастника в уголовном законодательстве отсутствует; при этом указывается, что ее не может заменить понятие соучастия в преступлении; одновременно констатируется, что она необходима как инструмент для правильного отражения фигур конкретных соучастников. Обращается внимание на то, что в теории определение соучастника встречается очень редко. Обычно исследование соответствующих вопросов соучастия сразу начинается с анализа видов соучастников. На основе критического анализа научных данных и нормативного решения выводится авторское определение соучастника. В отношении объема утверждается, что выделяемые законодателем виды соучастников преступления самодостаточны, перечислены исчерпывающе и добавлять к ним каких-либо других лиц нет необходимости. Лица, прибавляемые в литературе к действительным соучастникам, признаются частными случаями названных в законе фигур или вообще не относятся к соучастию. Вывод заключается в том, что в закон, с одной стороны, желательно ввести понятие соучастника преступления, с другой стороны, нецелесообразно включать новые виды соучастников.

Ключевые слова: содержание; объем; понятие; соучастник преступления; соучастие в преступлении; лицо; исполнитель; пособник; субъект преступления; соисполнитель; несоучастник; учинитель; виды соучастников преступления.

Для цитирования: Благов Е. В. О понятии соучастника преступления // Актуальные проблемы российского права. - 2021. - T. 16. — № 9. - C. 114-123. — DOI: 10.17803/1994-1471.2021.130.9.114-123.

\section{On the Concept of an Accomplice in a Crime}

Evgeniy V. Blagov, Dr. Sci. (Law), Professor, Professor, Department of Criminal Law and Criminology,

P. G. Demidov Yaroslavl State University

ul. Sovetskaya, d. 14, Yaroslavl, Russia, 150003

Blagov@uniyar.ac.ru

\begin{abstract}
The paper analyzes the content and scope of the concept of an accomplice in a crime. With regard to the content, it is noted that there is no definition of an accomplice in the criminal law. At the same time, it is indicated that it cannot be replaced by the concept of complicity in a crime. It is stated that it is necessary as a tool for the correct reflection of the figures of specific accomplices. Attention is drawn to the fact that in theory, the definition of an accomplice is very rare. Usually, research into relevant complicity issues begins immediately with an analysis of the types of complicity. On the basis of a critical analysis of scientific and regulatory decisions, the

(C) Благов Е. В., 2021

* Благов Евгений Владимирович, доктор юридических наук, профессор, профессор кафедры уголовного права и криминологии Ярославского государственного университета имени П. Г. Демидова

Советская ул., д. 14, г. Ярославль, Россия, 150003

Blagov@uniyar.ac.ru
\end{abstract}


author's definition of an accomplice is given. With regard to the content, it is argued that the types of accomplices in a crime identified by the legislator are self-sufficient and are listed exhaustively and there is no need to add any other persons. Persons specified in literature as real accomplices are recognized as special cases of the persons named in the law or do not belong to complicity at all. The conclusion is that, on the one hand, it is desirable to introduce into the law the concept of an accomplice in a crime, on the other hand, it is inappropriate to include new types of accomplices.

Keywords: content; range; concept; accomplice in a crime; complicity in a crime; face; executor; accomplice; subject of the crime; co-executor; non-participant; offender; types of accomplices in the crime.

Cite as: Blagov EV. O ponyatii souchastnika prestupleniya [On the Concept of an Accomplice in a Crime]. Aktual'nye problemy rossijskogo prava. 2021;16(9):114-123. DOI: 10.17803/1994-1471.2021.130.9.114-123. (In Russ., abstract in Eng.).

И з логики известно, что любые понятия имеют содержание и объем. В отношении же соучастника преступления Уголовный кодекс определяет лишь объем. В статье 33 УК РФ названы и описаны лица, которые признаются соучастниками. Причина, по которой не сформулирована нормативная дефиниция соучастника, может заключаться в том, что законодатель не увидел необходимости в этом в силу а) наличия понятия соучастия в преступлении, б) очевидности решения или в) слабой теоретической разработанности.

К определению, кто такой соучастник преступления, порой подходят просто, считая им лицо, «обладающее всеми признаками соучастия ${ }^{1}$. Такого не может быть хотя бы потому, что соучастник, очевидно, не способен обладать признаком двух или более лиц, без которого на основании ст. 32 УК РФ исключено соучастие в преступлении.

Причем понятия соучастия в преступлении и соучастника преступления отражают далеко не одно и то же. «Соучастие - уголовно-правовое явление, тогда как соучастник - особая категория лица, совершающего преступление...»; мало того, первое «представляет собой более широкое по объему понятие, в содержание которого входит и иная составляющая (формы соучастия)»².

Конечно, в нормативной дефиниции соучастия в преступлении называются некие лица.
И ясно, что именно они являются соучастниками преступления.

Однако термин «лицо» в уголовном законодательстве имеет множество оттенков. Он охватывает, в частности, совершившего преступления, образующие совокупность и рецидив (ст. 17, 18 УК РФ), подлежащего и не подлежащего уголовной ответственности (ст. 19, 21), виновного и невиновно причинившего вред (ст. 25, 28), совершившего оконченное и неоконченное преступление (ст. 29, 30), обороняющегося и посягающего (ст. 37).

Какое именно лицо подразумевается в качестве соучастника преступления, в законе не установлено. Соответственно, нет никаких ориентиров для выведения фигур конкретных соучастников. Может быть, вследствие этого с описанием некоторых из них возникли неувязки.

Если исполнитель - это соучастник преступления, то вопреки ч. 2 ст. 33 УК РФ он явно не может непосредственно совершать преступление без участия других соучастников или только с лицами, не являющимися соучастниками. Если пособник - соучастник преступления, то вопреки ч. 5 ст. 33 УК РФ он должен способствовать его совершению, а не укрывательству путем дачи заранее соответствующих обещаний.

Разумеется, решение о том, кто такой соучастник преступления, вытекает из известного русскому языку понятия соучастника и ст. 32 УК РФ. В русском языке соучастник - тот, кто

1 Рыжов Р. С. Уголовная ответственность соучастников преступления : дис. ... канд. юрид. наук. Рязань, 2003. С. 80.

2 Дрепелев А. С. Соучастник преступления. М., 2019. С. 33. 
участвует вместе с кем-нибудь в совершении чего-нибудь (обычно неблаговидного); причем значение слова "соучастник» соответствует значению слова "соучастие» как совместное участие в чем-нибудь (обычно неблаговидном) ${ }^{3}$. Отсюда при выведении определения соучастника преступления не грех пойти таким же путем.

Исходя из положений ст. 32 УК РФ, соучастником преступления можно бы считать лицо, умышленно участвующее совместно с хотя бы одним другим лицом в совершении умышленного преступления. Вместе с тем, несмотря на очевидность приведенного решения, адекватным его назвать трудно. Хотя дело не в нем самом, а в неудачности действующей редакции ст. 32 УК РФ.

Бросается в глаза, что законодатель, не мудрствуя лукаво, при выведении дефиниции соучастия в преступлении просто взял за основу подход, принятый в русском языке. Получилась же двойная тавтология: соучастие в преступлении - совместное участие в совершении преступления. Дело в том, что «со...» является приставкой, которая служит для образования существительных, означая общее совместное участие в чем-нибудь, а участие - деятельность по совместному выполнению чего-нибудь, сотрудничество в чем-нибудь ${ }^{4}$. Стало быть, законодательное понятие соучастия в преступлении неинформативно и тем самым не способно служить базой для выведения определения соучастника преступления.

Что касается теоретических исследований соответствующих вопросов соучастия в преступлении, то абсолютное большинство из них находится в фарватере закона. Они, как правило, сразу берут быка за рога и начинаются непосредственно с анализа видов соучастников преступления.
Имеющихся дефиниций соучастника преступления совсем не много. В литературе полагают следующее:

- соучастник - это лицо, вступившее в сговор с другим лицом (другими лицами) и согласившееся исполнить либо впоследствии исполнившее в объеме сговора любую роль в совершении преступления ${ }^{5}$. Приведенное понятие узко вследствие того, что, во-первых, учитывая ч. 1 ст. 35 УК РФ, при соучастии в преступлении сговор совсем не обязателен, а из изложенного решения вытекает, что в группе лиц соучастники якобы отсутствуют; во-вторых, по смыслу ст. 33 для признания лица соучастником достаточно выполнения им одной роли, а из определения следует, что согласившееся исполнить лишь конкретную роль в совершении преступления лицо соучастником не должно признаваться;

- соучастник - это лицо, отвечающее признакам субъекта преступления, умышленно участвовавшее в совместном совершении умышленного преступления, или соучастником является любое лицо, отвечающее закрепленным признакам, независимо от выполняемой роли, участвующее в совершении преступления ;

- соучастники преступления - лица, которые совместно участвовали в совершении предусмотренного статьей Особенной части УК умышленного преступления (или нескольких преступлений) ${ }^{7}$. Авторам последних дефиниций ставится в упрек их зависимость от понятия соучастия в преступлении ${ }^{8}$. В этом самом по себе нет абсолютно ничего предосудительного. Существование соучастника преступления возможно только в рамках соучастия, и отсюда он даже "должен отвечать основным признакам, которые в совокуп-

3 См.: Ожегов С. И. Толковый словарь русского языка. М., 2016. С. 1106.

4 См.: Ожегов С. И. Указ. соч. С. 1088, 1242.

5 См.: Галактионов Е. А. Соучастие и организованная преступная деятельность : дис. ... д-ра юрид. наук. СПб., 2002. С. 249-250, 259.

6 См.: Павлухин А. Н., Рыжов Р. С., Эриашвили Н. Д. Виды и ответственность соучастников преступления. М., 2007. С. 27, 29.

7 См.: Энциклопедия уголовного права. СПб. : Изд. проф. Малинина, 2007. Т. 6. С. 123.

8 См.: Дрепелев А. С. Указ. соч. С. 34. 
ности составляют понятие соучастия в преступлении»;

- соучастником преступления выступает лицо, подлежащее уголовной ответственности и совершившее умышленное преступление совместно с хотя бы одним таким же лицом ${ }^{10}$. Данный подход наиболее точен. В то же время он, во-первых, хотя и уходит от неопределенности законодательного термина «лицо», говоря о лице, подлежащем уголовной ответственности, но недостаточно.

В состав преступления повсеместно включается субъект преступления. Именно он - лицо, подлежащее уголовной ответственности. Тем самым в дефиниции соучастника желательно задействовать указание на самого субъекта преступления.

Во-вторых, критикуемая дефиниция уже вслед за законом а) включает ничего не объясняющий признак совместности и б) не уточняет вид умысла. И то, и другое снижает практическую значимость решения.

Объединяющий фактор соучастия в преступлении - взаимосвязь поведения соучастников. Она проявляется в том, что в соответствии со ст. 33 УК РФ деяния организатора, подстрекателя и пособника направлены прежде всего на обеспечение деяния исполнителя. Оно же соединяет деяния всех соучастников в единое преступление.

Как известно, в вопросе о виде умысла при соучастии в преступлении наука единством не отличается. Практика допускает соучастие в преступлении не только с прямым, но и с косвенным умыслом ${ }^{11}$.

Закон - слабое подспорье в решении вопроса о виде умысла при соучастии в преступлении. В статье 32 УК РФ сказано об умысле в целом, что в принципе способно означать и лишь прямой умысел, и оба вида умысла. Во всяком случае, практика исходит из того, что если убийство может быть совершено как с прямым, так и с косвенным умыслом, то покушение на убийство возможно только с прямым умыслом ${ }^{12}$, хотя как в ст. 30 УК РФ, так и в ст. 105 говорится просто об умышленных действиях (бездействии).

Правда, исходя из контекста закона, у соучастников преступления косвенный умысел не допустим. При нем, согласно ч. 3 ст. 25 УК РФ, лицо предвидит возможность наступления последствий, но не желает, а сознательно их допускает или относится к ним безразлично, что исключает совместность их причинения, а без совместности соучастия не бывает.

Давно уже отмечено, что косвенным умыслом охватывается психическое отношение к побочному продукту действий (бездействия), ведущих к совершению иного преступления или непреступного деяния; для возникновения же самого продукта лицо ничего не предпринимает ${ }^{13}$. Если соответствующее лицо для наступления побочного продукта - общественно опасных последствий - никаких действий (бездействия) не осуществляет, остальные лица - тем более.

При изложенных обстоятельствах соучастие как совместное участие в совершении преступления сложиться не может. Тем самым наличие у соучастников преступления косвенного умысла исключается. Все они должны совершать только прямоумышленное деяние.

Исходя из сказанного, для соучастия характерно совершение преступления лишь с прямым умыслом. Иной подход не отвечает смыслу закона.

Следовательно, соучастник преступления - это субъект преступления, свершивший

9 Павлухин А. Н., Рыжов Р. С., Эриашвили Н. Д. Указ. соч. С. 27.

10 См.: Дрепелев А. С. Указ. соч. С. 54.

11 См.: определение Судебной коллегии по уголовным делам Верховного Суда РФ по делу К. и М. // Бюллетень Верховного Суда Российской Федерации. 2008. № 9. С. 29 ; определение Судебной коллегии по уголовным делам Верховного Суда РФ от 01.02.2010 № 43-009-20 по делу Покатаева и Толстоброва // СПС «КонсультантПлюс».

12 См.: постановление Пленума Верховного Суда РФ от 27.01.1999 № 1 «О судебной практике по делам об убийстве (ст. 105 УК РФ)» // Бюллетень Верховного Суда Российской Федерации. 1999. № 3. С. 2 (п. 2).

13 См.: Дурманов Н. Д. Стадии совершения преступления по советскому уголовному праву. М., 1955. С. 123. 
прямоумышленное деяние во взаимосвязи с другим субъектом преступления. При наличии приведенной нормативной дефиниции было бы затруднительно раскрытие исполнителя и пособника с ранее приведенными и вызывающими сомнения признаками.

Разумеется, исполнителя нельзя сводить к указанному в ч. 2 ст. 33 УК РФ лицу, непосредственно участвовавшему в совершении преступления совместно с другими лицами (соисполнителями). Последние - тоже исполнители. Между тем и соисполнителей для адекватного понимания исполнителя недостаточно. В противном случае неясно, для чего в закон введены иные соучастники. Как следствие, исполнителем должно быть еще то лицо, которое совершило действия (бездействие), предусмотренные в соответствующей статье (ее части) Особенной части Уголовного кодекса, во взаимодействии с иным соучастником.

В литературе уже обращено внимание на то, что по закону исполнитель может быть как индивидуально действующим лицом, так и лицом, действующим в соучастии, и предложено вывести понятие исполнителя за пределы соучастия и отразить в разделе о субъекте преступления ${ }^{14}$. С таким подходом выражено несогласие ${ }^{15}$, подкрепленное ссылкой на положение теории еще советского уголовного права, согласно которому исполнитель преступления - понятие соотносительное; оно мыслимо только в соучастии, т. е. лишь в тех случаях, когда наряду с исполнителем действуют и лица, выполняющие иную функциональную роль: организаторов, подстрекателей и пособников; если же преступление совершается одним лицом, вопрос о его роли и функциях не возникает; в таких случаях речь идет просто о субъекте преступления ${ }^{16}$.

Возразить на приведенное несогласие было вовсе не сложно, что и сделано представите- лем идеи о выведении понятия исполнителя за пределы соучастия в преступлении. Им справедливо замечено, что соучастник - тоже субъект преступления; субъект преступления - это общая категория, включающая в себя и исполнителя, а кроме того, и организатора, подстрекателя, пособника ${ }^{17}$.

Одновременно несложно возразить и против идеи о выведении понятия исполнителя за пределы соучастия. С одной стороны, в действующем Уголовном кодексе нет раздела о субъекте преступления, но с другой стороны, даже если бы такой раздел был, перемещение в него понятия исполнителя, в сущности, ничего бы не дало: исполнитель все равно остается неким двуликим Янусом.

На поверку ничем не лучше предложение перенести положения ч. 2 ст. 33 УК РФ В ч. 2 ст. 19, но 4. 2 первой статьи изложить в следующей редакции: «Исполнителем преступления признается лицо, соответствующее признакам, указанным в 4. 2 ст. 19 настоящего Кодекса» ${ }^{18}$. Все лишь переворачивается: в отличие от закона, неисполнитель-соучастник включает в себя индивидуально действующего исполнителя, а последний - первого. Причем абсолютно не представить, как исполнитель-несоучастник может непосредственно участвовать в совершении преступления совместно с другими лицами (соисполнителями).

Приведенная полемика высветила давно назревшую проблему особого наименования и раскрытия лица, индивидуально (единолично, самостоятельно) совершившего преступление, ибо, разумеется, негоже одним термином обозначать и его, и соответствующего соучастника преступления. Общий термин затушевывает сущностные отличия охватываемых им разных субъектов преступления.

Исполнителя-несоучастника в принципе можно назвать лицом, совершившим преступ-

14 См.: Козлов А. П. Соучастие: традиции и реальность. СПб., 2001. С. 105.

15 См.: Рыжов Р. С. Указ. соч. С. 81.

16 См.: Бурчак Ф. Г. Учение о соучастии по советскому уголовному праву. Киев, 1969. С. 135.

17 См.: Козлов А. П. Указ. соч. С. 104.

18 См.: Алексеев С. В. Проблемы уголовной ответственности за преступления, совершаемые в группе : автореф. дис. ... канд. юрид. наук. Тамбов, 2006. С. 8. 
ление единолично ${ }^{19}$. Только обозначение получается громоздким.

Если исполнитель - тот, кто совершает преступление совместно с определенным лицом, то того, кто это делает без чьего-либо участия, можно именовать учинителем. Им вполне допустимо признать лицо, само совершившее действие (бездействие), предусмотренное статьей (ее частью) Особенной части Уголовного кодекса, а также лицо, совершившее то же самое посредством другого лица, не подлежащего уголовной ответственности в качестве соучастника преступления.

Напротив, для пособника в законе достаточно оставить указание лишь на соответствующее содействие совершению преступления. Дачу же определенных обещаний целесообразно полностью включить в предусмотренные ст. 175 и 316 УК РФ приобретение или сбыт имущества, заведомо добытого преступным путем, и укрывательство преступлений.

Признаваемые пособничеством обещания относятся к постпреступному поведению. То же, что происходит после совершения преступления, соучастием в самом преступлении быть не может по определению. Получается, что, исходя из ст. 32 УК РФ, любое обещание, названное в 4. 5 ст. 33, даже не является участием в преступлении, что исключает лицо, давшее таковое, из соучастия ${ }^{20}$.

Вообще возникают сомнения, что обещания было правильно криминализовать в качестве преступления. В русском языке обещание - добровольное обязательство что-нибудь сделать ${ }^{21}$. Однако подобное обязательство не может обладать общественной опасностью, ибо, с одной стороны, при нем в отношении указанных в ч. 1 ст. 2 УК РФ объектов уголовно-правовой охраны никакого действия не происходит, что, с другой стороны, могло бы происходить при его выполнении. Закон же этого не требует, да и не способен требовать. В противном случае было бы очевидно неучастие соответствующего пособника в преступлении. Не случайно в ст. 175 и 316 УК РФ ответственность установлена не за обещания приобрести или сбыть имущество, добытое преступным путем, либо укрывательства особо тяжких преступлений, а за сами приобретение, сбыт и укрывательство, если они заранее обещаны.

Объем понятия соучастника в преступлении в ст. 33 УК РФ представлен необходимым и достаточным образом. Признавать соучастником кого бы то ни было другого, помимо исполнителя, организатора, подстрекателя и пособника, нет никаких оснований.

Конечно, в литературе как возможные соучастники преступления называются заказчик, инициатор, посредник, участник организованной группы, корпоративный соучастник, провокатор, собственник или главный виновник преступления ${ }^{22}$. Кроме того, статусом соучастника предлагается наделить соисполнителя, организаторов различного уровня, организатора преступления или преступного формирования и руководителя преступления или преступного

19 См.: Бабий Н. А. Соучастие в преступлении: формы, виды, ответственность. М., 2015. С. 169.

20 См.: Арутюнов А. А. Соучастие в преступлении. М., 2013. С. 251.

21 См.: Ожегов С. И. Указ. соч. С. 1093, 642.

22 См.: Алексеев С. В. Указ. соч. С. 9 ; Калуцких Р. Г. Уголовно-правовые вопросы квалификации преступлений, совершенных в соучастии : автореф. дис. ... канд. юрид. наук. М., 2000. С. 6 ; Артеменко Н. В., Минькова А. М. Проблемы уголовно-правовой оценки деятельности посредника, провокатора и инициатора преступления в уголовном праве РФ // Журнал российского права. 2004. № 11. С. 51 ; Васюков В. В. Виды соучастников в уголовном праве России : автореф. дис. ... канд. юрид. наук. СПб., 2008. С. 9 ; Разинкин В. С. К вопросу о классификации и улучшении доказательственных возможностей института соучастия в организованной преступности // Уголовное судопроизводство. 2006. № 11. С. 22 ; Ермакова Н. В. Проблемы уголовно-правовой оценки деятельности посредника, провокатора и инициатора преступления в уголовном праве РФ; пути их решения // Проблемы и перспективы юриспруденции в современных условиях / ред. кол. Р. Г. Апсалямов [и др.]. Казань, 2015. Вып. 2. С. 52-53 ; Бабий Н. А. Указ. соч. С. 38. 
формирования ${ }^{23}$. Наконец, наряду с соучастниками преступления выделяются соучастники преступной деятельности: ее организатор, исполнитель и пособник ${ }^{24}$.

Исходя из нормативной терминологии, можно найти еще сонм якобы соучастников преступления. Так, в ст. 210 УК РФ говорится об участии в собрании организаторов, руководителей (лидеров) или иных представителей преступных сообществ (преступных организаций) и (или) организованных групп ${ }^{25}$. Из воспроизведенного делается вывод, что законом расширен круг субъектов, которых следует признавать соучастниками, поскольку за пределы организаторов выведены руководители, лидеры, иные представители ${ }^{26}$.

В теории обращено внимание на то, что в ч. 4 ст. 35 УК РФ упомянуты члены преступного сообщества (преступной организации) ${ }^{27}-$ вот основание для признания еще одной фигуры соучастника преступления.

Названными лицами поводы для выведения новых соучастников преступления не заканчиваются. Нормативные предписания дают немало доводов к противному. Если есть желание, несложно найти и других якобы соучастников. Так, упоминаются:

- В ст. 64 УК РФ - участник группового преступления;

- ст. 209 - участие в совершаемых бандой нападениях, т. е. можно выделить фигуру участника нападения;
- ст. 210 - координация действий организованных групп, создание устойчивых связей между ними, разработка планов и создание условий для совершения преступлений организованными группами, раздел сфер преступного влияния и (или) преступных доходов между такими группами, т. е. допустимо вычленить фигуры координатора, иного создателя - по отношению к организатору как лицу, создавшему организованную группу или преступное сообщество (преступную организацию), - и распределителя.

Правда, наверное, все-таки не следует строить на каждом более или менее подходящем словосочетании, обнаруженном в Уголовном кодексе и, вполне вероятно, даже не до конца продуманном ${ }^{28}$, теоретическую конструкцию отдельного вида соучастника преступления. Правильно отмечено, что бесконечное введение в закон новых терминов и понятий не только не позволит разрешить проблемы соучастия, но и может просто разрушить институт соучастия ${ }^{29}$.

Якобы новые соучастники либо в большинстве случаев являются формами проявления названных в законе фигур, либо (например, как провокатор), по существу, вообще не относятся к соучастию в преступлении. В статье 33 УК РФ на настоящий момент изложены деяния всех лиц, достойных самостоятельно считаться теми из двух или более из них, которые, на основании ст. 32, умышленно совместно участвуют в совершении умышленного преступления.

23 См.: Дядькин Д. С. Совершенствование уголовно-правового института соучастия в преступлении : автореф. дис. ... канд. юрид. наук. М., 2002. С. 22 ; Энциклопедия уголовного права. Т. 6. С. 250 ; Ситникова А. И. Уголовно-правовая текстология. М., 2016. С. 177.

24 См.: Покаместов А. В. Уголовно-правовая и криминологическая характеристика соучастия в преступной деятельности : автореф. дис. ... канд. юрид. наук. М., 2000. С. 20.

25 В части 1 ст. 228.1 УК РФ предусмотрено создание объединения организаторов, руководителей или иных представителей частей или структурных подразделений такого сообщества.

26 См.: Козлов А. П. Реалии, фикции и уголовное право // Уголовное право: истоки, реалии, переход к устойчивому развитию / отв. ред. В. С. Комиссаров. М., 2011. С. 44.

27 См.: Дрепелев А. С. Указ. соч. С. 71.

28 О том, что таковое встречается, свидетельствуют неоднократные изменения одних и тех же уголовно-правовых предписаний, крайний случай которых - исключение и повторное установление ответственности за клевету (ст. 129 и 128.1 УК РФ).

29 См.: Арутюнов А. А. Указ. соч. С. 147. 
Вместе с тем в теории оспаривается мнение, согласно которому деяние каждого из соучастников преступления самостоятельно, как якобы основанное «на неточном анализе норм о соучастии», ибо "тот факт, что функции соучастников различных видов могут пересекаться между собой, прямо вытекает из содержания закона». При этом вместо того, чтобы привести подтверждающие положения закона (которых просто нет), критик ссылается на научные представления и практику, в которых соучастник, подстрекающий к преступлению и способствующий его совершению, признается организатором ${ }^{30}$.

В противовес критику (но в его духе) можно указать на научное положение, согласно которому подстрекательство к преступлению и одновременное выполнение пособнических действий нельзя автоматически квалифицировать как организацию преступления ${ }^{31}$. Причем теоретики нередко исходят из того, что выполнение одним лицом деяний подстрекателя и пособника подлежит квалификации со ссылкой на ч. 4 и 5 ст. 33 УК РФ ${ }^{32}$, и имеется точно такая же практика 33

Таким образом, в закон, с одной стороны, желательно ввести понятие соучастника преступления, с другой стороны, нецелесообразно включать новые виды соучастников. Первое позволит уточнить фигуры исполнителя и пособника, а также обособить от исполнителя лицо, единолично совершившее преступление.

\section{БИБЛИОГРАФИЯ}

1. Алексеев С. В. Проблемы уголовной ответственности за преступления, совершаемые в группе : автореф. дис. ... канд. юрид. наук. - Тамбов, 2006. - 23 с.

2. Артеменко Н. В., Минькова А. М. Проблемы уголовно-правовой оценки деятельности посредника, провокатора и инициатора преступления в уголовном праве РФ // Журнал российского права. 2004. - № 11. - С. 48-54.

3. Арутюнов А. А. Соучастие в преступлении. - М. : Статут, 2013. - 408 с.

4. Бабий Н. А. Соучастие в преступлении: формы, виды, ответственность. - М. : Юрлитинформ, 2015. $744 \mathrm{c}$.

5. Бурчак Ф. Г. Учение о соучастии по советскому уголовному праву. - Киев : Наукова думка, 1969. 216 c.

6. Васюков В. В. Виды соучастников в уголовном праве России : автореф. дис. ... канд. юрид. наук. СПб., 2008. - 18 c.

7. Галактионов Е. А. Соучастие и организованная преступная деятельность : дис. ... д-ра юрид. наук. СПб., 2002. $-450 \mathrm{c}$.

8. Дрепелев А. С. Соучастник преступления. - М. : Юрлитинформ, 2019. - 208 с.

9. Дурманов Н. Д. Стадии совершения преступления по советскому уголовному праву. - М. : Госюриздат, 1955. - 212 с.

30 См.: Клименко Ю. А. Организатор преступления: понятие, виды, уголовно-правовое значение : дис. ... канд. юрид. наук. М., 2011. С. 94-95.

31 См.: Качалов В. В. Организатор преступления в уголовном праве России : автореф. дис. ... канд. юрид. наук. М., 2004. С. 9-10.

32 См.: Кладков А. Квалификация преступлений, совершенных в соучастии // Законность. 1998. № 8. С. 27 ; Сабитов Р. А. Теория и практика уголовно-правовой квалификации. М., 2013. С. 341.

33 См.: определение Судебной коллегии по уголовным делам Верховного Суда РФ по делу П. и С. // Бюллетень ВС РФ. 2001. № 7. С. 27 ; определение Судебной коллегии по уголовным делам Верховного Суда РФ № 41-008-75 по делу К. и Т. // Там же. 2009. № 5. С. 10. 
10. Дядькин Д. С. Совершенствование уголовно-правового института соучастия в преступлении : автореф. дис. ... канд. юрид. наук. - М., 2002. - 26 с.

11. Ермакова Н. В. Проблемы уголовно-правовой оценки деятельности посредника, провокатора и инициатора преступления в уголовном праве РФ; пути их решения // Проблемы и перспективы юриспруденции в современных условиях / ред. кол. Р. Г. Апсалямов [и др.]. - Казань : ИЦРОН, 2015. Вып. 2. - С. 50-53.

12. Зацепин А. М. Дополнительная квалификация преступления: общие и специальные вопросы. - М. : Проспект, 2017. - 304 с.

13. Калуцких Р. Г. Уголовно-правовые вопросы квалификации преступлений, совершенных в соучастии : автореф. дис. ... канд. юрид. наук. - М., 2000. - 24 с.

14. Качалов В. В. Организатор преступления в уголовном праве России : автореф. дис. ... канд. юрид. наук. - М., 2004. - 23 с.

15. Кладков А. Квалификация преступлений, совершенных в соучастии // Законность. - 1998. - № 8. С. 26-28.

16. Клименко Ю. А. Организатор преступления: понятие, виды, уголовно-правовое значение : дис. ... канд. юрид. наук. - М., 2011. - 220 с.

17. Козлов А. П. Реалии, фикции и уголовное право // Уголовное право: истоки, реалии, переход к устойчивому развитию / отв. ред. В. С. Комиссаров. - М. : Проспект, 2011. - С. 42-46.

18. Козлов А. П. Соучастие: традиции и реальность. - СПб. : Юридический центр-Пресс, 2001. - 362 с.

19. Ожегов С. И. Толковый словарь русского языка / под ред. А. И. Скворцова. - 27-е изд., испр. - М. : АСТ ; Мир и образование, 2016. - 1360 с.

20. Павлухин А. Н., Рыжов Р. С., Эриашвили Н. Д. Виды и ответственность соучастников преступления. М. : Юнити-Дана ; Закон и право, 2007. - 142 с.

21. Покаместов А. В. Уголовно-правовая и криминологическая характеристика соучастия в преступной деятельности : автореф. дис. ... канд. юрид. наук. - М., 2000. - 24 с.

22. Разинкин В. С. К вопросу о классификации и улучшении доказательственных возможностей института соучастия в организованной преступности // Уголовное судопроизводство. - 2006. - № 11. - С. 21-27.

23. Рарог А. И. Квалификация преступлений по субъективным признакам. - Спб. : Юридический центрПресс, 2003. - 304 c.

24. Рыжов Р. С. Уголовная ответственность соучастников преступления : дис. ... канд. юрид. наук. - Рязань, 2003. - $236 \mathrm{c}$.

25. Сабитов Р. А. Теория и практика уголовно-правовой квалификации : науч.-практ. пособие. - М. : Юрлитинформ, 2013. - 592 с.

26. Ситникова А. И. Уголовно-правовая текстология. - М. : Проспект, 2016. - 304 с.

27. Энциклопедия уголовного права. - Т. 6 : Соучастие в преступлении. - Спб. : Издание профессора Малинина, 2007. - 564 с.

Материал поступил в редакцию 25 сентября 2020 г.

\section{REFERENCES (TRANSLITERATION)}

1. Alekseev S. V. Problemy ugolovnoj otvetstvennosti za prestupleniya, sovershaemye v gruppe : avtoref. dis. ... kand. yurid. nauk. - Tambov, 2006. - $23 \mathrm{~s}$.

2. Artemenko N. V., Minkova A. M. Problemy ugolovno-pravovoj ocenki deyatelnosti posrednika, provokatora i iniciatora prestupleniya v ugolovnom prave RF // Zhurnal rossijskogo prava. - 2004. - № 11. - S. 48-54.

3. Arutyunov A. A. Souchastie v prestuplenii. - M. : Statut, 2013. $-408 \mathrm{~s}$.

4. Babij N. A. Souchastie v prestuplenii: formy, vidy, otvetstvennost. - M. : Yurlitinform, 2015. - $744 \mathrm{~s}$. 
5. Burchak F. G. Uchenie o souchastii po sovetskomu ugolovnomu pravu. - Kiev : Naukova dumka, 1969. — $216 \mathrm{~s}$.

6. Vasyukov V. V. Vidy souchastnikov v ugolovnom prave Rossii : avtoref. dis. ... kand. yurid. nauk. - SPb., 2008. $-18 \mathrm{~s}$.

7. Galaktionov E. A. Souchastie i organizovannaya prestupnaya deyatelnost : dis. ... d-ra yurid. nauk. - SPb., 2002. $-450 \mathrm{~s}$.

8. Drepelev A. S. Souchastnik prestupleniya. - M. : Yurlitinform, 2019. - $208 \mathrm{~s}$.

9. Durmanov N. D. Stadii soversheniya prestupleniya po sovetskomu ugolovnomu pravu. - M. : Gosyurizdat, 1955. - $212 \mathrm{~s}$.

10. Dyadkin D. S. Sovershenstvovanie ugolovno-pravovogo instituta souchastiya v prestuplenii : avtoref. dis. ... kand. yurid. nauk. - M., 2002. - 26 s.

11. Ermakova N. V. Problemy ugolovno-pravovoj ocenki deyatelnosti posrednika, provokatora i iniciatora prestupleniya v ugolovnom prave RF; puti ih resheniya // Problemy i perspektivy yurisprudencii v sovremennyh usloviyah / red. kol. R. G. Apsalyamov [i dr.]. - Kazan : ICRON, 2015. - Vyp. 2. - S. 50-53.

12. Zacepin A. M. Dopolnitelnaya kvalifikaciya prestupleniya: obshchie i specialnye voprosy. - M. : Prospekt, 2017. - $304 \mathrm{~s}$.

13. Kaluckih R. G. Ugolovno-pravovye voprosy kvalifikacii prestuplenij, sovershennyh v souchastii : avtoref. dis. ... kand. yurid. nauk. - M., 2000. - $24 \mathrm{~s}$.

14. Kachalov V. V. Organizator prestupleniya v ugolovnom prave Rossii : avtoref. dis. ... kand. yurid. nauk. - M., 2004. $-23 \mathrm{~s}$.

15. Kladkov A. Kvalifikaciya prestuplenij, sovershennyh v souchastii // Zakonnost. - 1998. — № 8. - S. 26-28.

16. Klimenko Yu. A. Organizator prestupleniya: ponyatie, vidy, ugolovno-pravovoe znachenie : dis. ... kand. yurid. nauk. - M., 2011. - $220 \mathrm{~s}$.

17. Kozlov A. P. Realii, fikcii i ugolovnoe pravo // Ugolovnoe pravo: istoki, realii, perekhod k ustojchivomu razvitiyu / otv. red. V. S. Komissarov. - M. : Prospekt, 2011. - S. 42-46.

18. Kozlov A. P. Souchastie: tradicii i realnost. - SPb. : Yuridicheskij centr-Press, 2001. - $362 \mathrm{~s}$.

19. Ozhegov S. I. Tolkovyj slovar russkogo yazyka / pod red. A. I. Skvorcova. - 27-e izd., ispr. - M. : AST ; Mir i obrazovanie, 2016. - $1360 \mathrm{~s}$.

20. Pavluhin A. N., Ryzhov R. S., Eriashvili N. D. Vidy i otvetstvennost souchastnikov prestupleniya. - M. : YunitiDana ; Zakon i pravo, 2007. - $142 \mathrm{~s}$.

21. Pokamestov A. V. Ugolovno-pravovaya i kriminologicheskaya harakteristika souchastiya $v$ prestupnoj deyatelnosti : avtoref. dis. ... kand. yurid. nauk. - M., 2000. - $24 \mathrm{~s}$.

22. Razinkin V. S. K voprosu o klassifikacii i uluchshenii dokazatelstvennyh vozmozhnostej instituta souchastiya v organizovannoj prestupnosti // Ugolovnoe sudoproizvodstvo. - 2006. - № 11. - S. 21-27.

23. Rarog A. I. Kvalifikaciya prestuplenij po subektivnym priznakam. - SPb. : Yuridicheskij centr-Press, 2003. $304 \mathrm{s.}$

24. Ryzhov R. S. Ugolovnaya otvetstvennost souchastnikov prestupleniya : dis. ... kand. yurid. nauk. - Ryazan, 2003. - $236 \mathrm{~s}$.

25. Sabitov R. A. Teoriya i praktika ugolovno-pravovoj kvalifikacii : nauch.-prakt. posobie. - M. : Yurlitinform, 2013. - $592 \mathrm{~s}$.

26. Sitnikova A. I. Ugolovno-pravovaya tekstologiya. - M. : Prospekt, 2016. - $304 \mathrm{~s}$.

27. Enciklopediya ugolovnogo prava. - T. 6 : Souchastie v prestuplenii. - SPb. : Izdanie professora Malinina, 2007. - $564 \mathrm{~s}$. 